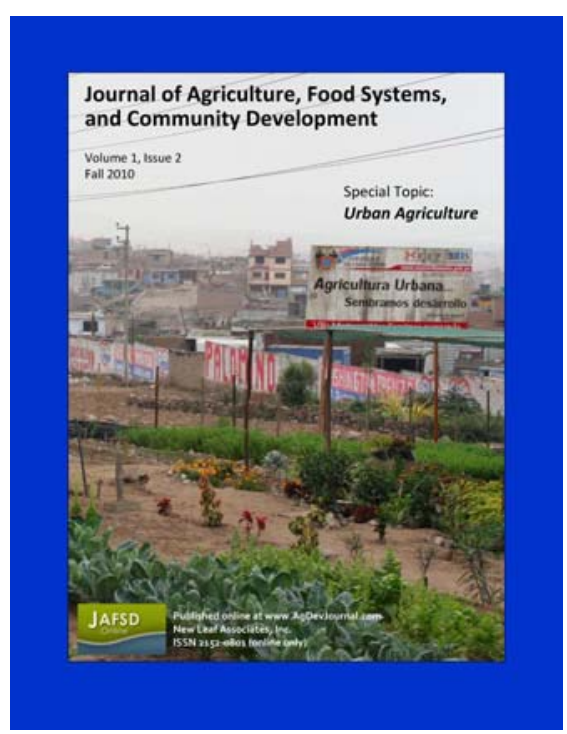

\author{
IN THIS ISSUE \\ DUNCAN HILCHEY
}

\title{
Frontiers in urban and peri-urban agriculture
}

Published online February 2011

Citation: Hilchey, D. (2010, Fall). In this issue: Frontiers in urban and peri-urban agriculture. Journal of Agriculture, Food Systems, and Community Development, 1(2): 1-3. doi:10.5304/jafscd.2010.012.016

Copyright (C) 2011 by New Leaf Associates, Inc.

\section{Important note from the publisher: JAFSCD is now following an advance publication schedule - and subscribers receive notification of new postings!}

JAFSCD is dedicated to publishing the most up-to-date applied research on agriculture and food systembased community development. To further this mission, we are "prepress" publishing our content, beginning with this issue. Instead of waiting for all of the accepted papers, commentaries, columns, and book reviews to be completed before publishing an entire issue, we are publishing all content online as it is ready.

The publishing process is a long one, especially for a peer-reviewed journal. Prepress publishing will get timely material in your hands as quickly as possible. If you're a subscriber, you'll automatically receive announcements of new content via our iContact email list. You can also sign up for the RSS feed to receive notifications immediately. To do this, click on the orange feed icon for each category of article in which you are most interested.

\section{Introduction to Urban Agriculture}

The special topic focus of JAFSCD volume 1, issue 2, is urban and peri-urban agriculture. While urban and peri-urban agriculture are common and often traditional aspects of food systems in the Global South, they are now on the rise in industrial countries as well, especially among ethnic immigrant groups in North America and Europe. The Food and Agriculture Organization (FAO) of the United Nations defines urban agriculture as "an industry that produces, processes and markets food and fuel, largely in response to the daily demand of consumers within a town, city, or metropolis, on land and water dispersed throughout the urban and periurban area, applying intensive production methods, using and reusing natural resources and urban wastes to yield a diversity of crops and livestock."1 The findings of national censuses, household surveys, and research

\footnotetext{
${ }^{1} \underline{\text { http://en.wikipedia.org/wiki/Urban agriculture }}$
} 
projects suggest that up to two-thirds of urban and peri-urban households around the world are involved in agriculture. Much of the food produced is for their own consumption, with occasional surpluses sold to local markets. $^{2}$

The expansion of urban and peri-urban agriculture is fueled by family economic situations as well as by growing interest among agencies and NGOs in greening and revitalizing cities, localizing food production, and promoting food sovereignty. These trends in urban and peri-urban agriculture are also accompanied by debates on related issues that include land use, public health, sanitation, and economic viability. Our intent for this special-topic call for papers is to help fill the significant deficit in the applied literature on trends and programming activities.

I want to express my appreciation to Anni Bellows and Joe Nasr, along with their colleague Gabriela Alcaraz V., for the colossal effort they put into our special tribute to Jac Smit, who passed away in 2009. Jac is sometimes referred to as the "father of urban agriculture" for his long career dedicated to bringing attention to urban agriculture and cultivating its expansion throughout the world. Jac's legacy continues in the work of Anni and Joe — and countless others — who were deeply inspired by his intellect and passion.

\section{In This Issue}

Rami Zurayk reveals the ephemeral nature in urban and peri-urban farming in the Middle East and the need for more stability in his Global Views of Local Food Systems column. John Ikerd's The Economic Pamphleteer column "Zoning Considerations for Urban and Peri-Urban Agriculture" suggests using zoning ordinances to restrict farming to sustainable activities. And Ken Meter challenges the conventional wisdom of economic multipliers in his Metrics from the Field column.

This issue's papers offer a smorgasbord of views on food production in a wide range of urban environments. Kathryn Colasanti and Michael Hamm estimate the capacity of the most famous American Rust Belt city Detroit - to tap into its potential to produce food. In contrast, Rod MacRae and colleagues look at the capacity of the thriving metropolis of Toronto to increase its food production. Using Flint, Michigan, as an example, planners Megan Masson-Minock and Deirdra Stockmann offer a tool for North American cities to inventory ordinances that can affect the proliferation of urban agriculture. Mary Beckie and Eva Bogdan present the results of pilot project that uses SPIN gardening to help integrate immigrants into the community. In the context of Lima, Peru, Marielle Dubbeling, Gunther Merzthal, and Noemi Soto describe how a thoughtful stakeholder engagement process helps institutionalize urban agriculture and insure its sustainability. Lydia Oberholtzer, Kate Clancy, and J. Dixon Esseks reveal the challenges and opportunities of producers in the shadows of growing urban areas around the United States. Terri Evans and Christiana Miewald evaluate a new urban marketing strategy being put to use in Vancouver, Canada: the pocket farmers' market. Charlie French, Mimi Becker, and Bruce Lindsay offer a provocative look at "Havana's Changing Urban Agriculture Landscape.” And Laura Witzling, Michelle Wander, and Ellen Phillips study lead levels in a sample of community gardens in Chicago and make recommendations for testing, education, and abatement.

Finally, Dawn Thilmany McFadden reviews Wendell Berry's collection of essays, Bringing It to the Table: On Farming and Food, and Phil Mount reviews the USDA Economic Research Service's "Comparing the Structure, Size, and Performance of Local and Mainstream Food Supply Chains," which includes a series of recent supply chain case studies in the U.S.

\footnotetext{
2 http://www.fao.org/ag/magazine/9901sp2.htm
} 


\section{Forthcoming in Issue 1, Volume 3}

Look for these articles to be available online as soon as they are through the publishing process:

- In "Integrated Policy for Achieving Sustainable Peri-urban Fruit and Vegetable Production to Reach Healthy Consumption Targets in Victoria, Australia," R. Carey, Kathy McConell, and colleagues examine that city's challenge in protecting its Green Wedges - traditional peri-urban production areas.

- In "Building Gardens, Rebuilding a City: Baltimore's Community Greening Resource Network," Sarah Krones and Shari Edelson describe Baltimore's successful adaptation of Detroit's highly regarded Garden Resource Program Collaborative.

- In "Smallholder Peri-Urban Organic Farming in Nepal: A Comparative Analysis of the Farming Systems," Gopal Bhatta documents the highly differentiated production strategies in Kathmandu, and makes a case for organic production as a viable alternative.

We appreciate your support and feedback as we continue publishing applied research on the intersection of agriculture and community development!

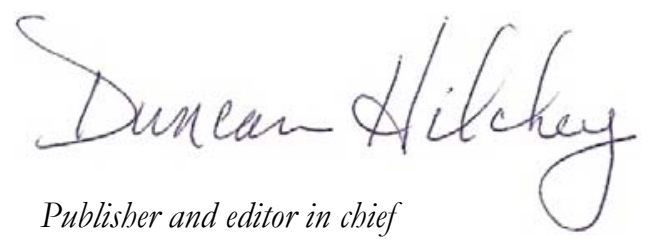


Journal of Agriculture, Food Systems, and Community Development ISSN: 2152-0801 online www.AgDevJournal.com 